\title{
Best Practices in Promoting Faculty-Student Interaction in Online STEM Courses
}

\section{Mr. Thomas M. Freeman, Michigan Technological University}

Thom Freeman Sr. Instructional Designer, Online Learning Specialist, and Adjunct Instructor - Michigan Technological University

Thom Freeman provides faculty and academic departments at Michigan Technological University with Instructional Design services, LMS Support, and assistance with the design, development, and administration of distance learning programs and online learning. He teaches graduate education courses in online teaching and integrating educational technology into teaching and learning. M. Ed. - Education and Human Development - The George Washington University

\section{Dr. Michelle E. Jarvie-Eggart, Michigan Technological University}

Dr. Jarvie-Eggart is a registered professional engineer with over a decade of experience as an environmental engineer. She lectures in the Engineering Fundamentals department at Michigan Technological University. Her research interests include online learning, active and collaborative learning, sustainability and diversity in engineering. 


\section{Best Practices for Promoting Faculty-Student Interactions in Online STEM Courses}

\section{Introduction}

In this paper two experienced veterans in the fields of online teaching and supporting instructors in teaching online will detail several best practices in promoting faculty-student interaction in online courses. New advances in technology, modern tool alternatives, and the unique demands faced by those teaching science, technology, engineering, and mathematics (STEM) courses online will be considered and addressed as well.

Faculty-Student interaction is vital to the success and quality of any online course. The need to develop a rich sense of active instructor presence in online learning has never been greater. Recently The US Department of Education ${ }^{[1]}$ and the Higher Learning Commission ${ }^{[2]}$ (HLC) have required "regular and substantive interaction between the students and the instructor" [1] in online courses. Additionally, research has consistently shown that a strong sense of instructor presence and frequent and meaningful faculty-student interactions improve student persistence ${ }^{[3]}$, satisfaction ${ }^{[4]}$, and achievement ${ }^{[5]}$ in online courses. This paper will provide instructors with several evidence-based techniques and methods to incorporate effective, meaningful, and STEM-friendly faculty-student interactions into their online courses. The practices are based on our experience, and included in the Specific Review Standards of the Quality Matters ${ }^{\mathrm{TM}}$ Higher Education Rubric Sixth Edition. ${ }^{[6]}$

\section{Introduce yourself and the course: Being Present from the Beginning}

While being present throughout the course is critical, starting as you mean to go on is also important. The Quality Matters ${ }^{\mathrm{TM}}$ Higher Education Rubric Sixth Edition Specific Review Standard 1.8 requires a professional self-introduction by online instructors ${ }^{[6]}$. Providing a personal video introduction at the start of the course allows students to see you as a human being which can mitigate the anonymity of text-based conversation and encourage human connections. Bandwidth limitations used to encourage instructors to limit the use of video in online learning, but in today's broadband world short videos (ideally 6 minutes or less) ${ }^{[7]}$ are functional and make your course seem more like the internet experience your students are accustomed to.

One of the first things you normally do in your class is introduce yourself. In an online class, introductions are even more important as they are one of the first points of contact with you as an instructor and likely the first one where they see you visually. Video introductions help your students feel more connected to you and lets them know there is a real, live faculty member behind the course. They support teaching presence, which is essential to online success ${ }^{(3,)(4),(5)}$. 
Research on video introductions indicates that they can improve student engagement at the beginning of the course and encourage positive student perceptions of you as the instructor ${ }^{[8]}$. The Center for Teaching and Learning noted instructor-made videos can help create a sense of instructor presence, breath life into online courses, and reduce feelings of isolation among students ${ }^{[9]}$.

Begin the semester by personally introducing yourself and sharing your background, expertise, and interests in a welcoming manner. This shows your students that you are approachable and interested in their learning. Creating a basic introduction video is also a great way to start thinking about using video and audio more generally, which diversifies the methods of communication and information delivery in your course. Simple webcam recordings are fine as long as you make sure your lighting and audio are good.

\section{Welcome to Foundations of Teaching Online}

\section{Welcome!}

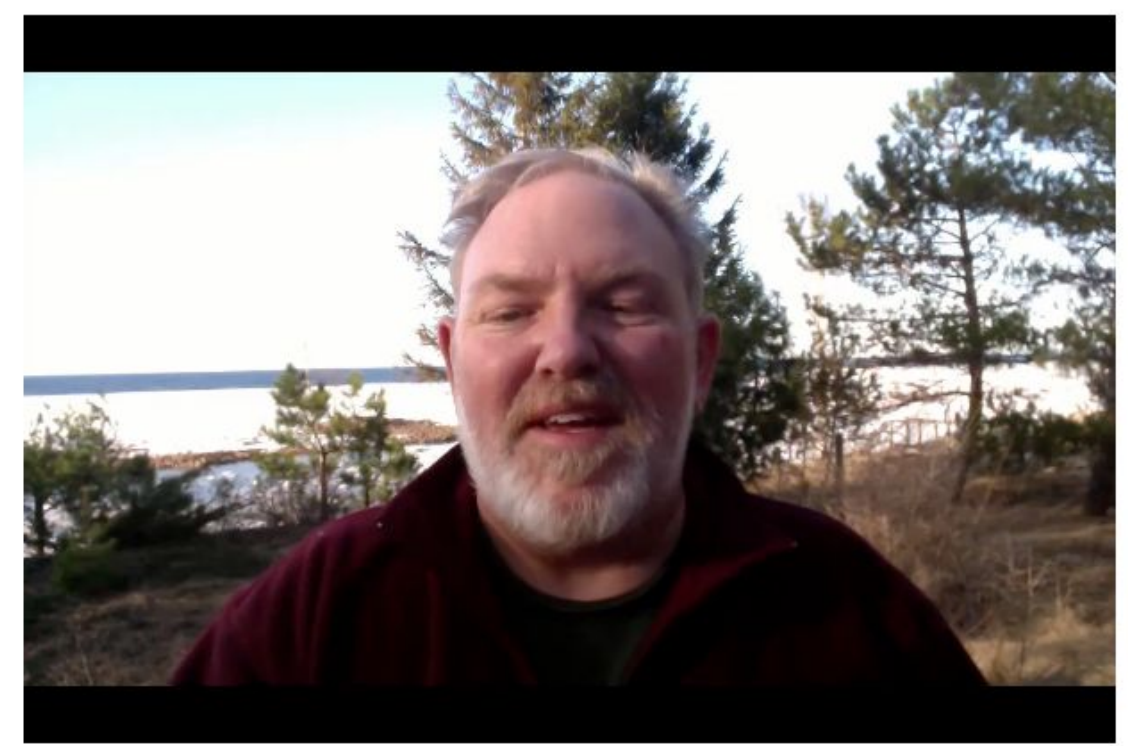

Welcome video transcript 速

This course is for those with previous teaching education or experience who are developing and/or teaching an online course or planning to. It explores the backwards design process beginning with learning outcomes, followed by assessments, activities and content,

Figure 1. Course and instructor introduction video.

Now that you have introduced yourself to your online course, have your students introduce themselves to you and the class in an Introduce Yourself discussion. The Quality Matters ${ }^{\mathrm{TM}}$ Higher Education Rubric Sixth Edition Specific Review Standard 1.9 requires that online learners be requested to introduce themselves in the online class ${ }^{[6]}$. This and your introduction video can be part of the first module or unit of your course along with activities to ensure 
students can access the important elements of your course, view the syllabus and are familiar with the course schedule. You will want to instruct them to post a brief introduction of themselves and include basic information including their name, where they live, where they are currently working, and what they like to do in their free time. Also, tie in some very basic information that relates to the course as a way to finish off their introduction. This could often be an example of how they might use something from the course in their workplace. Some examples might include asking them to include why they are taking this course, how they hope to use the knowledge gained from this course in their careers, what they hope to base their final project or paper around, etc. This helps turn some of the discussion that ensues back toward the course. It is good practice to instruct students to make an initial timely post of their introduction and then return to the Introduce Yourself discussion sometime prior to the end of the first unit or module to reply to a couple of their classmates. Although some of this information may be the same for some working professionals from one course to the next while pursuing a graduate degree or certificate, it is strongly suggested that each course begin like this to encourage students to engage with the instructor and each other and reduce feelings of isolation right from the start. Doing so has been shown to improve student persistence ${ }^{(3)}$, satisfaction ${ }^{(4)}$, and achievement $^{(5)}$ in online courses.

Be sure to reply to each student's introduction with a brief welcome to the course message. In general, best practice is to not reply to every student's post in an online discussion, but in this case you will want to just briefly say 'hi' back to them to make sure they feel welcome and that their introduction was appreciated.

You will also want to encourage the use of pictures and video by your students here. Today's modern learning management systems feature tools to include video and images in discussion posts. Including directions on how to add video and images into their discussion posts within the instructions of your Introduce Yourself discussion will encourage your students to add a picture or video of themselves in their post. 


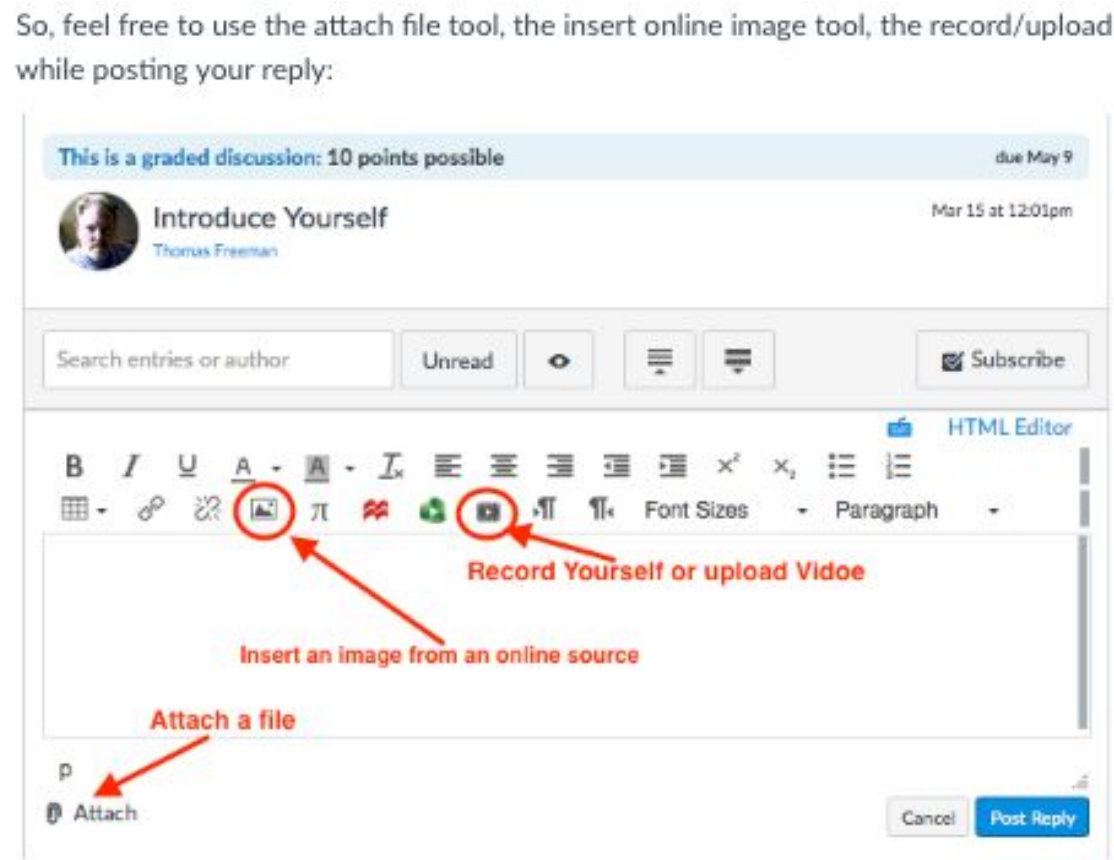

The combination of your video introduction and their use of video and images in their Introduce Yourself discussion post will help your students feel like they are really getting to know you and each other, and will allow you to feel like you are getting to know them too. This encourages the development of an online community of learners and will help promote more faculty-student interactions in your course by setting a friendly, collegial tone right from the start. "Students with a stronger sense of community in online courses are more likely to feel positive about their educational experience and persist in their educational programs than students who feel isolated" [10], [11].

\section{Frequency of logon for both students/faculty}

Research has shown that one of the elements students value most about in-person education is interaction with faculty ${ }^{[12\},[13]}$. Maintaining quality interactions in the online environment is a major focus of most online instructors. In this area, we must lead by example. Instructors should begin by clearly stating their own frequency of logon to class. Logging on every day is desirable, but may not be practical for instructors with family obligations on the weekends. Logging on every other day may be a more realistic expectation for instructors. Your University may have a policy on this. Check your faculty handbook to see if there is a time stipulated by which you must respond to students online or in email. It is most often either 24 or 48 hour response time. Whichever you select as a logon frequency, it is important to clearly communicate it so that students know how often to expect you in class and how long turnaround time will take on 
discussion postings. Once you have explained what students can expect from you as an instructor, you can then clearly state your expectations for student logon.

It is good practice to ask students to plan on logging into your class a certain number of days each week. Most college courses meet three days per week. It is reasonable to expect your students to logon to class at least three days each week. Be clear about when discussion posts are due in class so that students can plan accordingly. Some adult working professionals choose to $\log$ on to class on the weekends to do their work, as they are busy with day jobs during the week. Request that your students post in class to let you and their peers know when they will be absent for more than a couple of days. Model communicating long absences in class for your students. If you plan on being away from the internet for the whole weekend, post a message on Friday explaining why and when students can expect to see you back. For example, Michelle might tell students "It is hunting season in the northwoods and my family will be at our camp this weekend without cell or internet service. If you need to get a hold of me, please be patient until I return on Monday. Have a great weekend and I look forward to catching up with you all when I return!”

\section{Virtual Office Hours}

Maintaining instructor office hours is a well-established practice and requirement in face-to-face education. Research has indicated that students use online office hours similar to their use of face-to-face office hours ${ }^{[14]}$. Virtual office hours are a critical part of engaging and interactive online courses. In a 2010 study, Edwards and Helvie-Mason found that "Seventy percent of the students' responses in this study were favorable toward VOHs (Virtual Office Hours) [15]",

Office hours are not only a big help for your students, but can assist you as an instructor too. If your students know they are strongly encouraged to drop-in to your online office hours for any reason at all, and those office hours are easy for your students to access, you can cut down on the number of student emails. Additionally, making yourself available at specific times can help limit making yourself available at any time!

When scheduling virtual office hours for working professionals it is good practice to offer hours at varying times of day. One approach could be to schedule a couple of hours during the typical work day and a seperate session of an hour or two in the evenings or on the weekend. Thom runs his online courses with modules which begin on Wednesdays and end on Tuesdays to give working professionals who take his course the choice to do much of their coursework and discussions on the weekends if they need to, while maintaining the flexibility for students to take the weekends off if their work schedules allow. He has two virtual office hours sessions, one Thursday afternoons and one on Monday nights. This gives those who want or need to connect from work the opportunity to do so, and allows those who want or need to connect 
outside of work to do so as well. Offering office hours at different times of day can also help mitigate the effects of differing time zones. In this particular case it also affords students one chance to talk and share screens with the instructor at the beginning of each new online module, and a second chance one day before the end of each online module when the main deliverables are due.

Today's modern video conferencing tools have come a long way and can make virtual office hours easy for both you and your students. Solutions such as Zoom, Cisco WebEx, GoToMeeting, Adobe Connect, etc., all afford users clear audio and video, the choice to have more than one student attending at a time, and the ability to easily share computer screens and use a whiteboard or document camera. Your institution most likely has a high quality video conferencing solution already in place, which you should use preferentially. In the event that your institution does not have an institutional contract with a specific video conferencing platform, there may be video conferencing capabilities built into your learning management system. If not, you can use freely available video conferencing through Google Hangouts, Skype, etc.

The capability to share screens and use document cameras and whiteboards available in video conferencing tools during virtual office hours can be a big asset for online STEM courses. This can allow both you and your students to draw circuits, forces, mathematical equations, free body diagrams, etc. Sharing computer screens allows instructors to demonstrate processes and have real-time discussions of the type of complex problems often faced in STEM courses. These virtual office hours can provide a similar experience as face-to-face office hours do. As a biochemistry instructor pointed out in the journal Biochemistry and Molecular Biology Education, "For example, I use application sharing and Protein Explorer to show biomolecular structures during the virtual office hours ${ }^{[16]}$ ".

\section{Managing Student Questions}

Clearly communicate your preferred mode of contact (email, discussion boards, virtual office hours, class messages/email, or phone contact). The Quality Matters ${ }^{\mathrm{TM}}$ Higher Education Rubric Sixth Edition Specific Review Standard 1.3 requires that communications expectations be clearly stated in online classes, specifically addressing "how learners are to communicate online" [6]. Make sure to check your university's policy on student communications. Turn around time for communication via email should be clearly stated to your students. Can they expect responses within 24 hours or 48 ? Check your faculty handbook as it may have guidelines about this. Thom directs student questions about the course to a general course Q \& A discussion board and/or virtual office hours. Frequently encouraging the use of a general course Q \& A discussion board in your short videos and module introductions can save instructors time. All students enrolled in 
a class are able to view instructor answers to common course questions, which can reduce the number of emails, text or calls an instructor receives about general course questions. At the start of a course, student questions may be mainly about class logistics before you delve into content. Early discussions in a course Q \& A discussion board encourages students to feel good about asking questions and seeking clarification.Your online course Q \& A discussion board provides a viewable history of the interaction for the whole class which virtual office hours, emails, texts and calls do not. Students can see that they often have the same questions as their peers, and asking them helps everyone get the answer more easily. However, some questions are best discussed in real time.

The use of virtual office hours facilitates more elaborate interactions than email and texts. When appointment slots are provided, virtual office hours provide students with the privacy not afforded by a course Q \& A discussion board. Questions about individual grades and performance should be directed to virtual office hours, as well as email, calls and texts. When discussing individual grades in virtual office hours, special care should be taken to make sure your discussion room is set up in a way that other students can't electronically "drop in" and turn a private conversation into a public one. Remember that the Family Education Rights and Privacy Act (FERPA) requires you to keep this information private ${ }^{[17]}$. Appointment slots for online office hours where grades are discussed may be best. For these conversations emails, calls and texts may be more convenient.

Some schools prefer for all communication to occur through official school resources (university email address, online classes and university phones). Additionally, for your own protection, you may desire a record of contact with students. For these reason, many instructors direct student questions to email or class messaging systems if they cannot attend virtual office hours. Email/messaging allows a dialogue to occur between students and instructors, but there is a time lag in communication.

In today's smartphone filled world, texting is rapidly becoming a method by which students desire to contact instructors. Many instructors choose to give out their personal cell numbers for student calls and texting. Consult your faculty handbook first to see if this is allowed. If it is, it is still best to place limits on when students can use your cell. For example, Michelle allows her students to call her from 9:00 am to 7:00 pm and text anytime, with an explanation that if students text late at night she may take a while to get back to them. She also tells her students that if they want the fastest response they should text her and not email. 


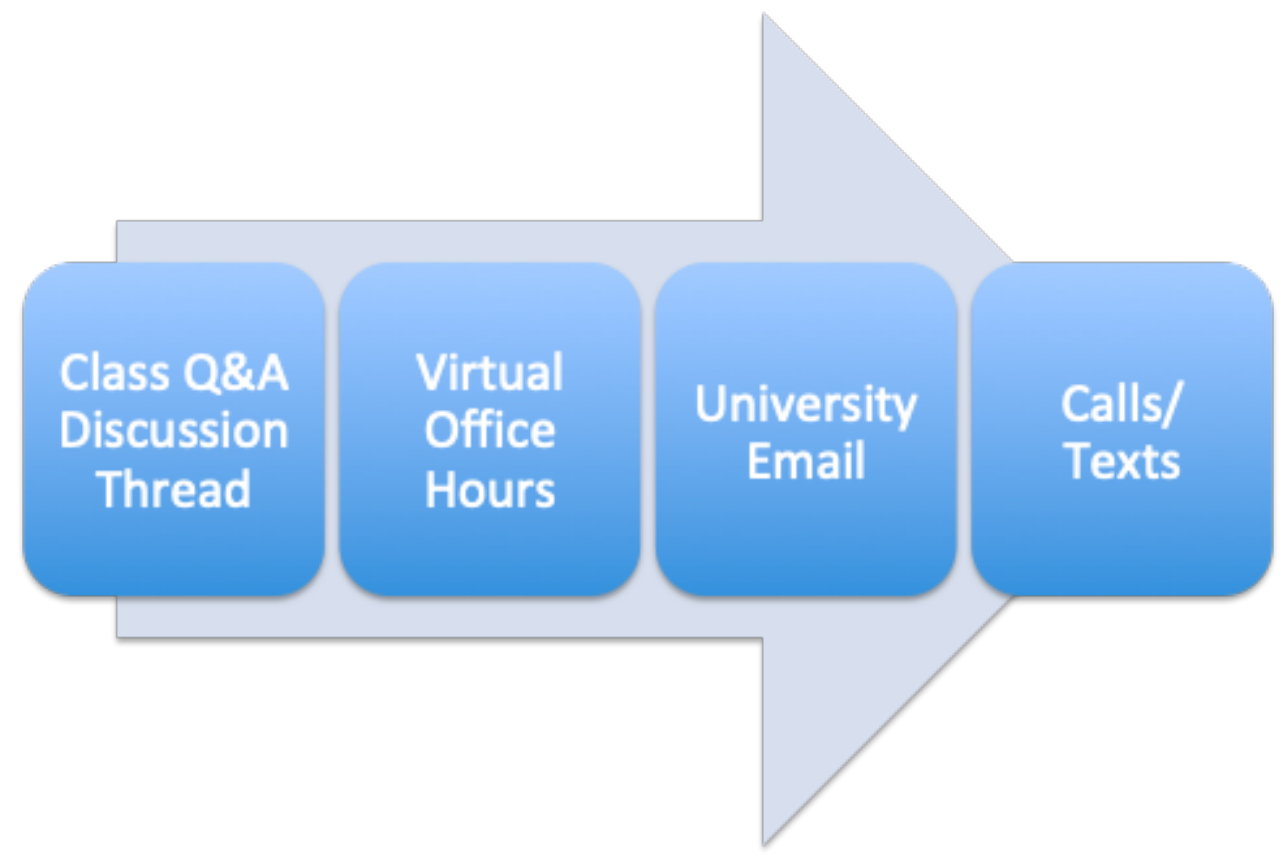

Figure 2. Order of Direction for Questions about Class and Grades.

\section{Online Class Discussions}

The Quality Matters ${ }^{\mathrm{TM}}$ Higher Education Rubric Sixth Edition Specific Review Standard 1.3 on communication expectations also requires that instructors clearly state expectations for online discussions ${ }^{[6]}$. It is difficult for meaningful online discussions to develop when students only participate in online courses in the weekends, For this purpose, it is wise to provide staggered deadlines throughout the week for original discussion postings and responses to peers in class. For example, instructors might choose to make original discussion posts to online discussion questions due on a Thursday or Friday, with responses to peers due on Sunday or Monday. When an initial discussion post is due earlier in the week, it allows time for peers to read it and post responses. More meaningful discussions, with a natural back and forth, can develop before the next week's discussion is due. Establishing a late policy on discussion posts helps enforce these deadlines. Michelle utilizes a 10\% penalty for each day a discussion post is late. She finds this policy insures that most of the students are posting by the initial due date.

Clear expectations must also be provided about what constitutes a meaningful (full credit) post. All posts should have proper citations of references (with embedded web links were appropriate). The preferred format for referencing should be communicated (MLA, APA, IEEE, etc). Expected length of discussion posts should be established. These vary by instructor and course. Whatever you choose for a length, it must be made clear to students that "I agree with Sheila" does not qualify as a substantive discussion post. A well written discussion rubric will 
consolidate these requirements and make it clear to students that discussion postings and peer responses are expected by a certain date, of a minimum length, address the question asked, and with proper references/citations.

To further guide students in developing online discussions, it is also useful to suggest they ask open-ended questions. Model this in your own discussion questions and responses to the students. Avoid asking any questions which can be answered with a simple yes or no. For example, instead of asking "Do you plan on getting your Professional Engineers license?" (which can be answered yes/no), you might ask "What is a Professional Engineers License? In what circumstances do engineers utilize them? How might this be useful to you in your career?" In "Supporting Learning Engagement with Online Students," Buelow, et al, discovered in their December 2018 study that "...discussion forums were most popular as engagement tools among

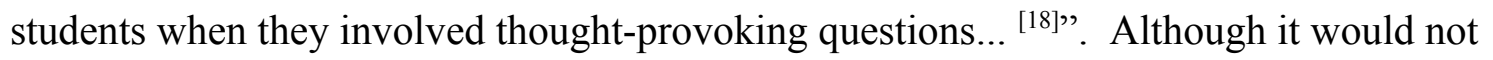
necessarily promote or increase faculty-student interactions, assigning a two to three person team of students to be student moderators of that unit or module's discussion can increase student engagement in discussions. The students will need to be instructed in how to draw out responses of their fellow classmates and ask those types of open-ended questions. They can then post a summary of that discussion when it is completed.

It is also essential to clearly state your expectations for respectful online communication. It is likely your university already has issued specific statements about zero tolerance for harassment for you to include in your syllabus. The Quality Matters ${ }^{\mathrm{TM}}$ Higher Education Rubric Sixth Edition Specific Review Standard 1.4 requires course/institutional policies be communicated to students, or the provision of a link to the current policy ${ }^{[6]}$. Check with your faculty handbook for these. In addition to the "canned" university statement, it is wise to remind students how easily tone can be misread online and in emails. Emphasize that it is important we all give each other the benefit of the doubt when reading online dialogue, while assuring the students that you can and will step in if discussions become disrespectful. Make it clear that you will follow university guidelines and report harassment in an online environment just as you would in a physical classroom.

Certain third party discussion board alternatives can lend themselves nicely to some online STEM courses. The following are some examples of additional platforms that allow students to more deeply analyze technical readings and work together on questions where there is only one correct answer.

$\mathrm{Nb}$, an online text annotating and discussion application developed by the Massachusetts Institute of Technology, allows a class to reference by highlighting, then annotate and discuss an 
exact section of text uploaded by the instructor as a PDF. It can also help foster deeper examination of technical readings by students.

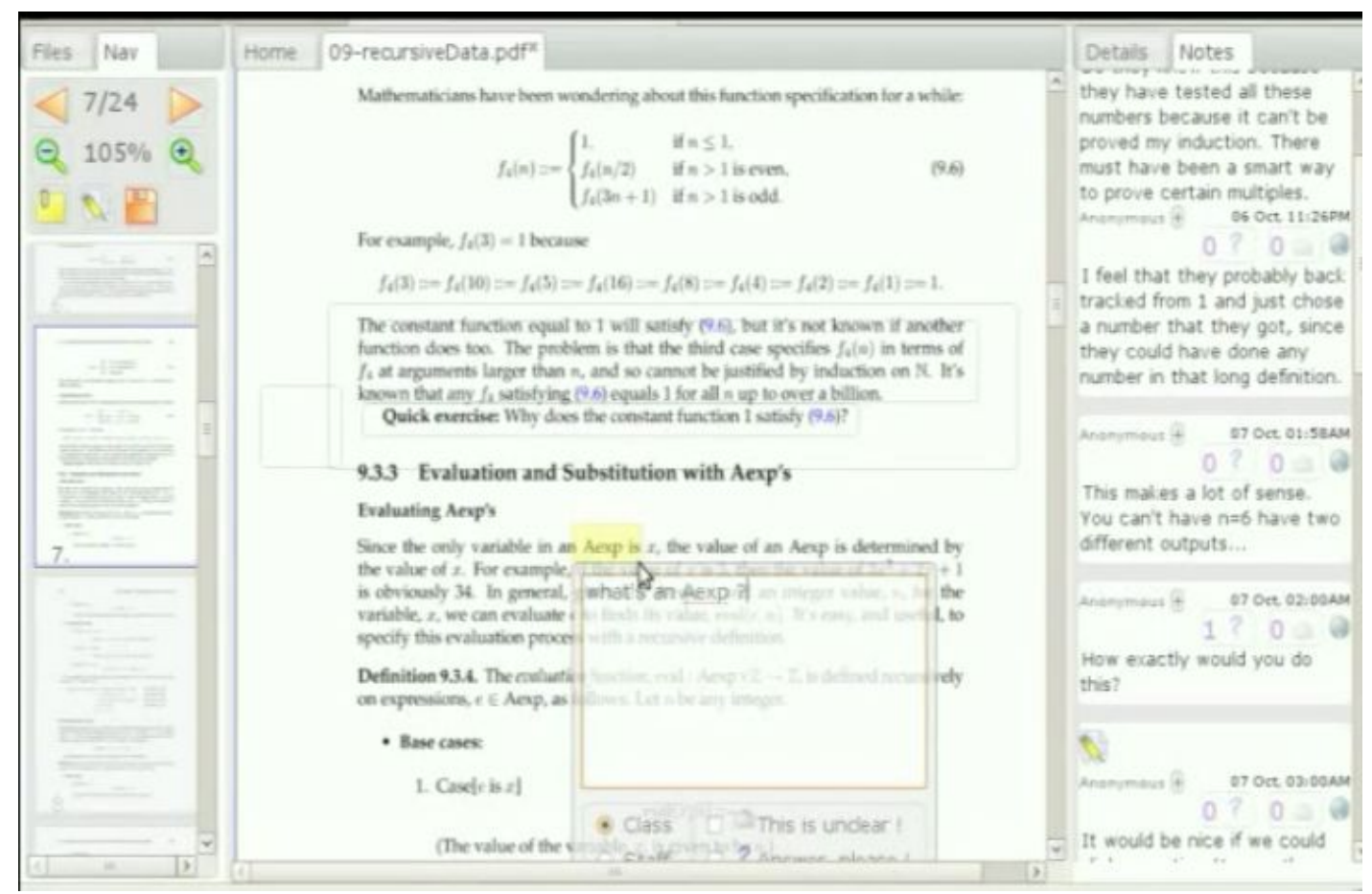

Figure 3. Student highlighting text and asking a question in $\mathrm{Nb}$.

Piazza is a wiki-style discussion forum that lends itself to the kind of questions with just one right answer. Each question has a single students' answer that students can contribute to, and a single instructors' answer that instructors can contribute to. With wiki-style Q\&A, when a student has a question, s/he doesn't need to sift through long threads in a forum to find what they are looking for, they can read just the single, high-quality question and answer. 


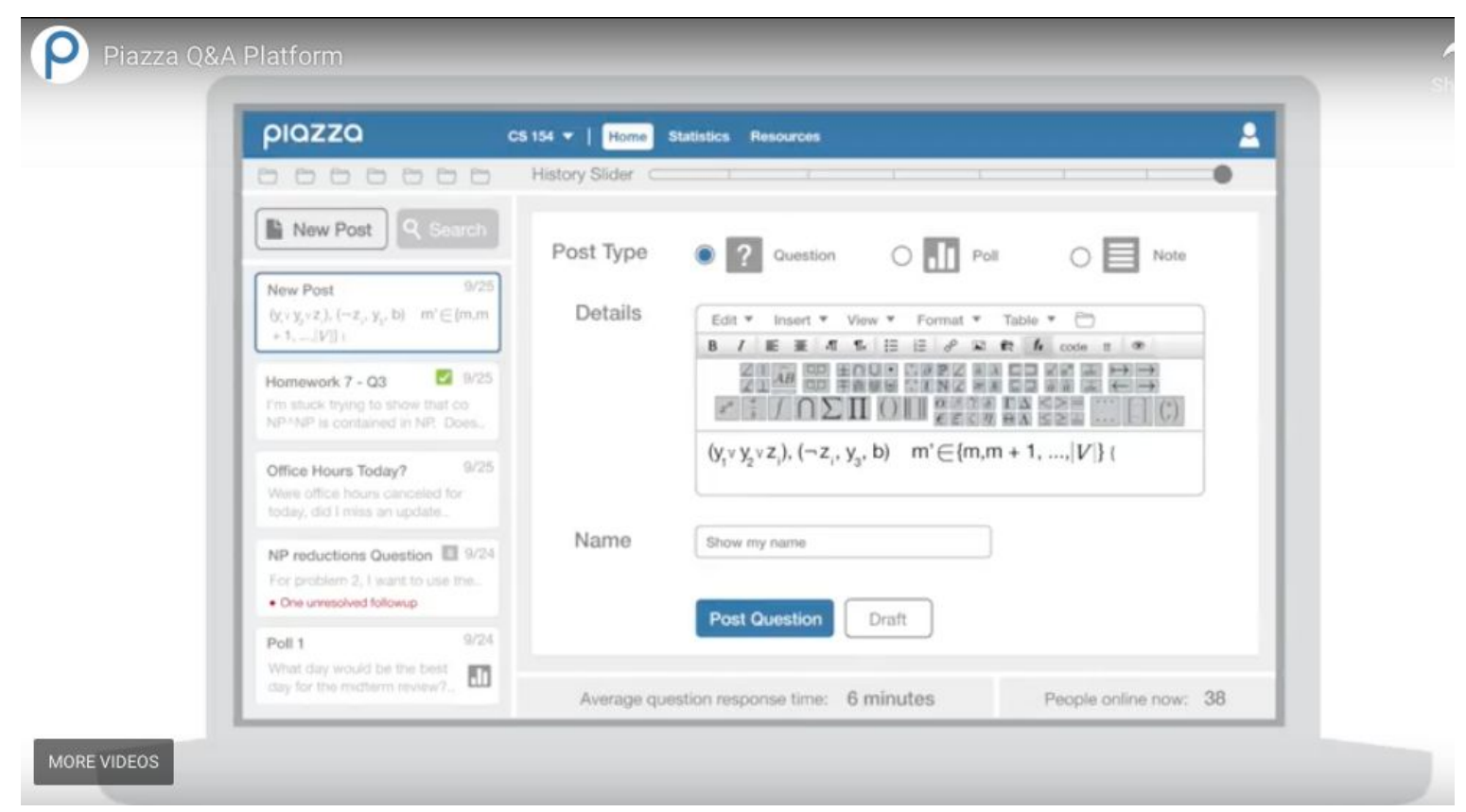

Figure 4. Piazza Q \& A Platform.

Perusall is another forum tool for students to annotate and discuss your class readings. Instructors can order and assign textbooks, articles, or PDFs in Perusall. Students annotate the readings and asynchronously respond to each other's comments and questions about the readings in context.

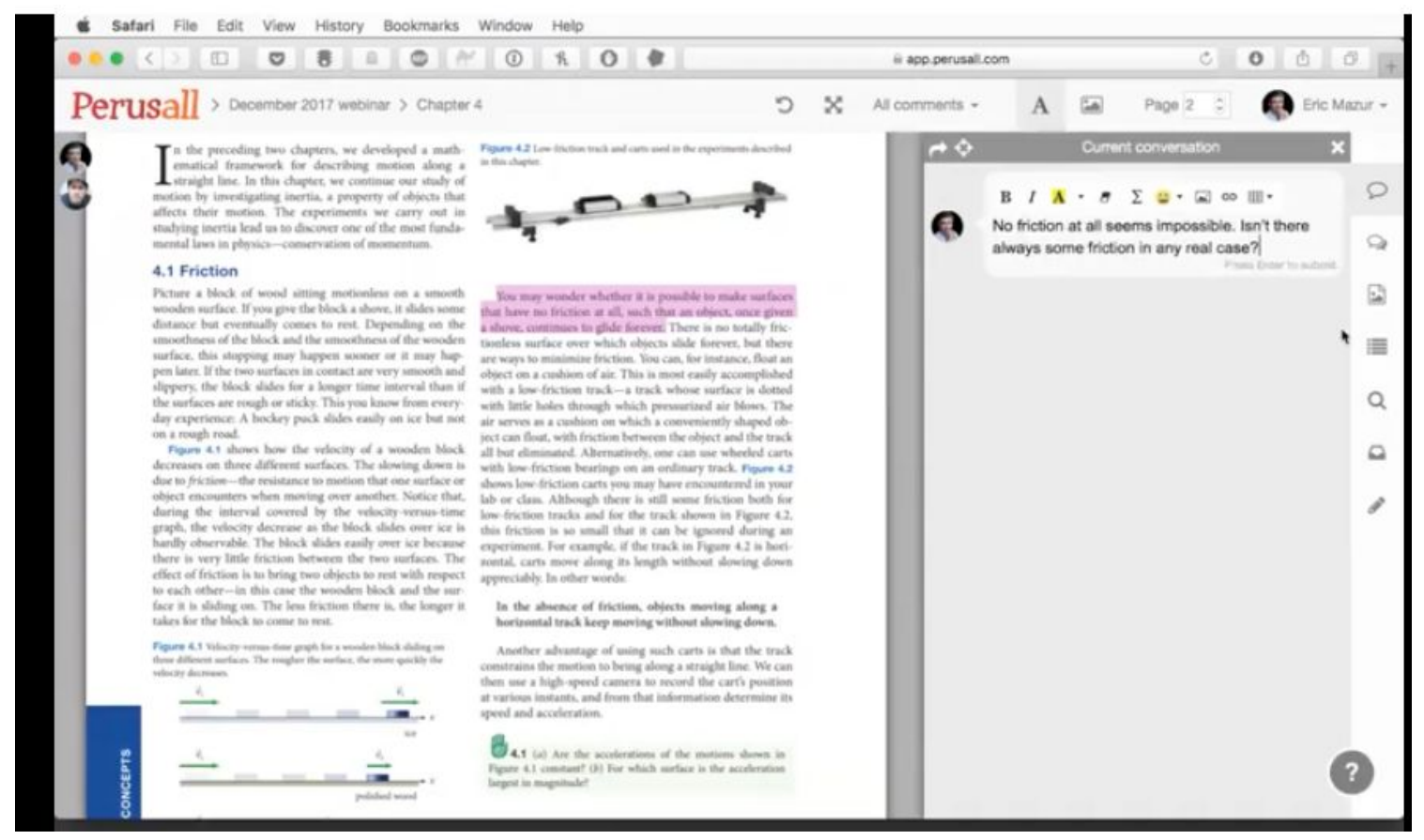

Figure 5. Perusall text discussion and Q \& A Platform. 


\section{Introducing Online Course Content with Short Instructor Videos}

Once you've introduced yourself and the course in a short video in the beginning of the first unit or module in your course it is important to continue being present in your course to show your students you are a real human being who cares about them and how they are doing. Continue to introduce each successive unit or module with a short, guide-on-the-side instructor video. It is a chance every unit or module for you to speak directly to students in-person, creating a stronger sense of instructor presence. Research has consistently shown that a strong sense of instructor presence and frequent and meaningful faculty to student interactions improve student persistence $^{(3)}$, satisfaction $^{(4)}$, and achievement ${ }^{(5)}$ in online courses. It will also go a long way towards turning your online course into a rich and engaging experience for your learners.

These short unit or module introductions by you should not be lectures. They should be a brief overview and roadmap about what's to come in the upcoming unit or module, telling the students both what is included and where to find it. The Quality Matters ${ }^{\mathrm{TM}}$ Higher Education Rubric Sixth Edition Specific Review Standard 1.2 requires that online students be introduced to the structure and purpose of the course ${ }^{[6]}$. Tell your students what they are going to do, when things will be due, how they are going to do them, what to watch out for or focus on, and how they might do well on this upcoming unit or module's assignments. You will also want to make these videos timely. Create them as close as you can to the start of the new unit or module and comment on the students' and the class' activities in the previous one. Mention things they will recognize that happened in the last module if possible. This will make it clear you're not just present, you're present right now! You are not just some canned recording, it's actually you talking directly to them today about what just happened a couple days ago and what's coming up. 


\section{Welcome to Module 1: Course Planning with Backwards Design and Learning Objectives}

Module 1: January 23 - February 5

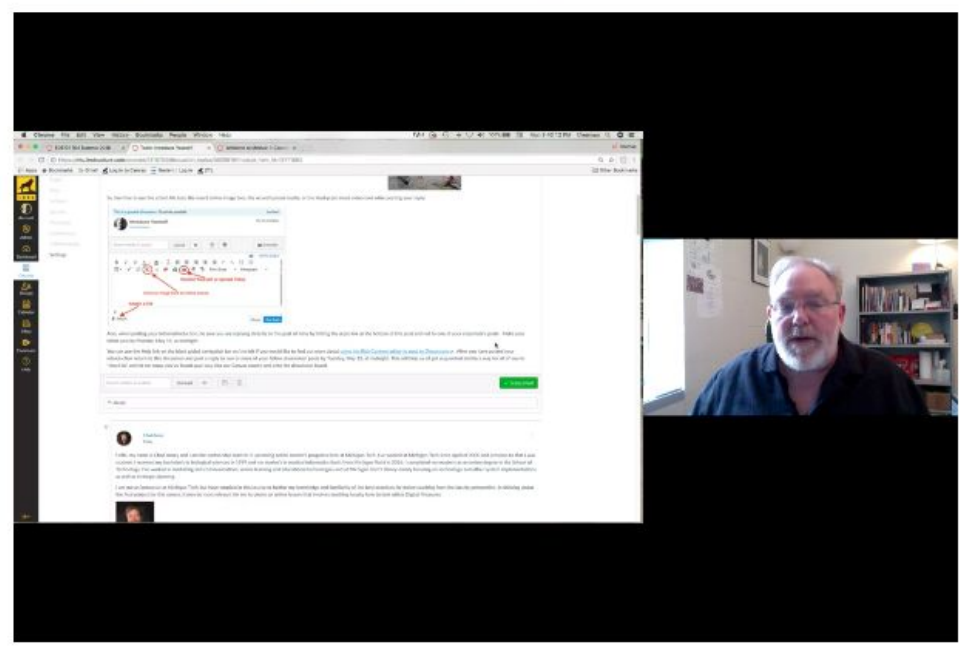

In this module we begin the process of reconceiving what you will teach and how you will teach it online, both for a future online course

Figure 6. Introduction to a course module.

Another great use of video, and another way to promote faculty to student interactions and create a stronger sense of instructor presence in online STEM courses is to insert additional short videos focused on your computer screen, a document camera, or a tablet. Working problems or drawing diagrams on a document camera or tablet, or using your computer screen to demonstrate a process or how to use some particular software on upcoming assignments can really help your students while keeping you more present in your online course. A summary of Hegeman's findings in "Using Instructor-Generated Video... in Online Mathematics Courses Improves Student Learning" revealed that students "performed better on all summative assessments, earned a statistically significant higher percentage of passing grades, and that their attrition rate dropped considerably ${ }^{[19]}$ " in sections of the online mathematics courses that included instructor-generated video when compared to online sections of the same course that did not.

Make sure to keep your videos short and to the point. Modern video recording, storing, and streaming solutions like Panopto, MediaSite, and Echo360, will allow you to have your computer screen /document camera/tablet in one window and your head shot in a smaller window side-by-side for an even greater sense of instructor presence. 


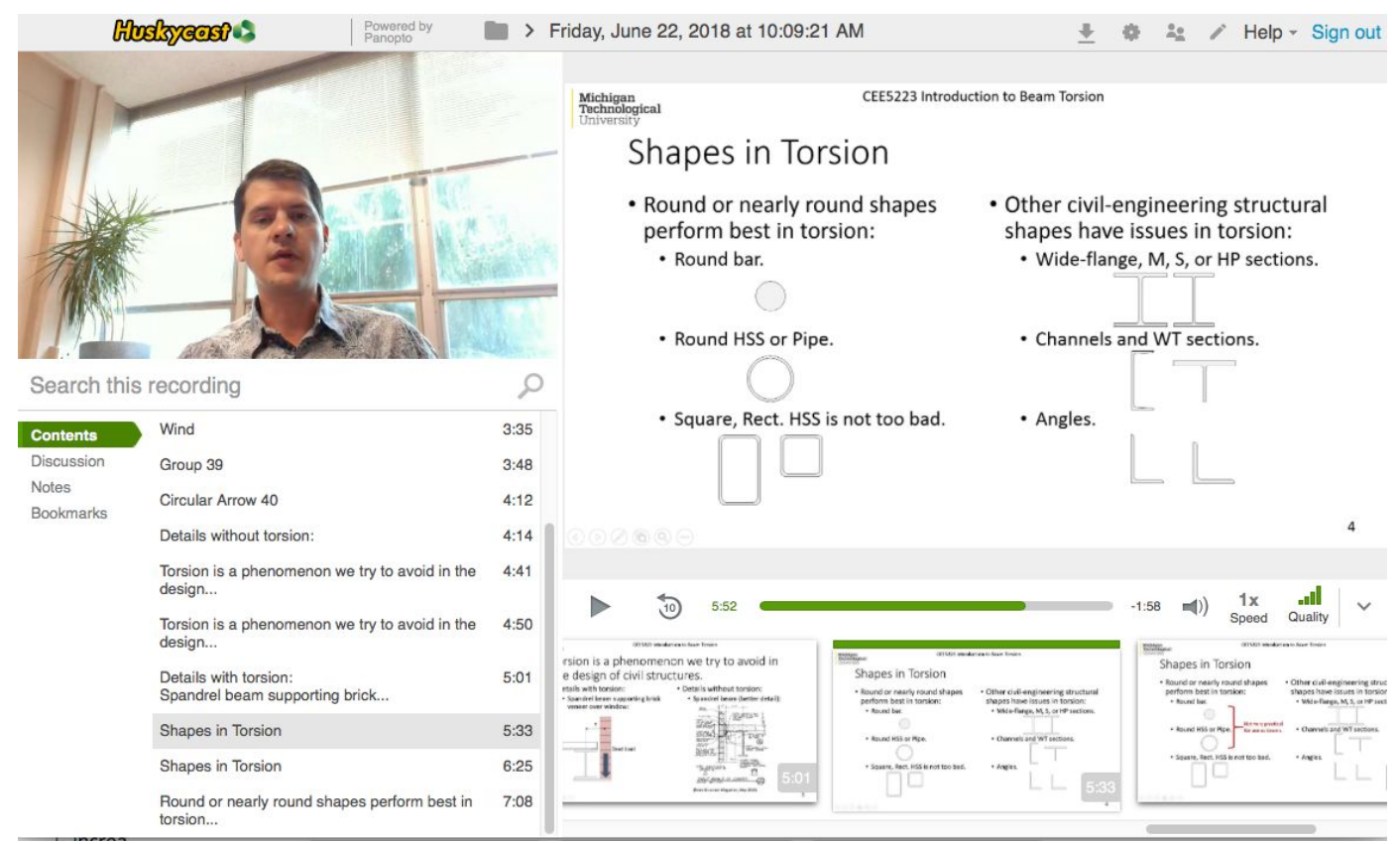

Figure 7. Short video of instructor working torsion problems.

\section{Instructor Feedback and Teaching Presence}

Instructor feedback on assignments in online courses is possibly the most important way in which you can promote instructor-student interactions and create a stronger sense of instructor presence in your online course ${ }^{[20]}$. In an online course it is important for students to get frequent feedback on how they are doing. Are they learning what they are supposed to be learning? Are they achieving the learning outcomes? Structuring feedback on submitted student work into the design of your online course right from the start is essential. The most effective way to ensure that students get the feedback they need to stay on track is through a comprehensive, balanced assessment strategy that includes both formative and summative assessments. Design each unit or module such that students submit an assignment for which they can get formative feedback from you that they can use directly to improve their work on that module's summative assessment or project at the end. Examples of this include rough drafts submitted prior to a final version, smaller sets of problems prior to an exam, giving feedback on homework which mirrors upcoming higher stakes assignments, online quizzes which can be taken multiple times until students master the material, or a smaller, low stakes version of the larger, higher stakes assignment at the end of that unit. Your feedback needs to be meaningful, frequent, timely, and include specific suggestions for improvement ${ }^{[21]}$ where ever possible. Structuring these formative feedback opportunities into each module or unit of your online course is a highly effective way to promote faculty-student interactions and create a stronger sense of instructor presence. It also allows you to really help your students succeed and interact with them in positive and meaningful ways directly about their work in your course. Your institution's 
Learning Management System will have feedback tools built right into its assignment submission mechanism so you can comment directly on their submission and they can reply back. This creates a feedback and reply loop engaging you and your students in faculty-student interactions focused directly on how they are doing on course assignments.

\section{Conclusion}

The best practices and tips gathered in this article are based on our years of experience teaching online and supporting online instruction. A welcome video and students introductions provide students with an increased sense of instructor presence, increases student engagement, reduces feelings of isolation, and helps students to feel more connected with each other, the instructor, and the class. To maintain your own presence in the class and keep dialogue rolling, set an expectation for yourself and the students of logging on at least three times a week. Maintain virtual office hours in a video platform where students can see your face and get to know you if they drop in. Manage student questions by directing general questions about the course to an online discussion for that purpose. Set clear expectations with a rubric for online class discussions. Introduce each online module with a short video explaining to students what is expected and/or clarifying sticky points from the last module. Feedback should be meaningful, frequent, and timely, and both formative and summative assessments should be included in your online course. Implementing these strategies will help ensure success in your online teaching and make your online course a rich and engaging experience.

\section{References}

1. US Department of Education. "Electronic Code of Federal Regulations." October 11, 2018.

http://www.ecfr.gov/cgi-bin/text-idx?SID=45333f1baff1 fb4eb6289b4caaf4ed50\&mc=tru e\&node $=$ se $34.3 .60012 \& \operatorname{rgn}=\operatorname{div} 8$

2. Higher Learning Commission. "Background Information on Distance and Correspondence Education.” 2018. https://www.hlcommission.org/Accreditation/distance-delivery.html

3. Richardson, J, Besser, E. Koehler, A. Lim, J. and Strait, M. Purdue University. “Instructors' Perceptions of Instructor Presence in Online Learning Environments". International Review of Research in Open and Distributed Learning. Volume 17, Number 4. June 2016. https://files.eric.ed.gov/fulltext/EJ1108404.pdf

4. Ladyshewsky, R. "Instructor Presence in Online Courses and Student Satisfaction," International Journal for the Scholarship of Teaching and Learning. Vol. 7, No. 1, Article 13. 2013. https://doi.org/10.20429/ijsotl.2013.070113 
5. Sandercock, I. "How Important Is Instructor Presence in an Online Course?" TeachOnline - Resources for Teaching Online. Arizona State University. October 13, 2014. https://teachonline.asu.edu/2014/10/important-instructor-presence-online-course/

6. MarylandOnline, Inc., "The Quality Matters ${ }^{\mathrm{TM}}$ Higher Education Rubric Sixth Edition." 2018.

7. Guo, P., Kim, J., Rubin, R. "How Video Production Affects Student Engagement: An Empirical Study of MOOC Videos.” 2014. CSAIL-MIT. Available: http://up.csail.mit.edu/other-pubs/las2014-pguo-engagement.pdf

8. Dulaney, E. and T. States. 2014 "How to Make the Most of a Video Introduction for an Online Course." Campus Technology. Available:

https://campustechnology.com/articles/2014/06/11/how-to-make-the-most-of-a-video-intr oduction-for-an-online-course.aspx

9. Davis, G. "Five Great Uses of Video in Online Courses." Center for Teaching and Learning | Learning House Inc.. April 19, 2018. Available: https://ctl.learninghouse.com/five-great-uses-of-video-in-online-courses/

10. Tinto, V. (1993). "Leaving college: Rethinking the causes and cures of student attrition". (2nd ed.). Chicago: University of Chicago Press.

11. Rovai, A. P. (2003). "Strategies for grading online discussions: Effects on discussions and classroom community in internet-based university courses". Journal of Computing in Higher Education, 15(1), 89-107. doi:http://dx.doi.org/10.1007/BF02940854

12. Hill, Y., Lomas, L., and MacGregor, J., "Students' Perceptions of Quality in Higher Education." Quality Assurance in Education. Vol. 11, No. 1, p. 15 - 20. 2003.

13. Jarvie-Eggart, M. "What Students Value about Education and Recommendations for Online Education." Journal of Online Engineering Education. Vol 8., No. 1., Article 1. 2017. Available: http://www.onlineengineeringeducation.com/joee_v8n1a1.pdf

14. Li, L, and Pitts, J. P. "Does it Really Matter? Using Virtual Office Hours to Enhance Student-Faculty Interaction.” Journal of Information Systems Education. Vol 20., No, 2. 2009.

15. Edwards, J.T., and Helvie-Mason, L. "Technology and Instructional Communication: Student Usage and Perceptions of Virtual Office Hours.” MERLOT Journal of Online Learning and Teaching. Vol. 6, No. 1, March 2010. Pp. 174-186. Available: http://jolt.merlot.org/vol6no1/edwards_0310.pdf

16. Kohorst, K, and Cox, J. R, "Virtual office hours using a tablet PC: E-lluminating biochemistry in an online environment." Biochemistry and Molecular Biology Education. Volume 35, Issue 3, May/June 2007, Pp. 193-197. Available: https://iubmb.onlinelibrary.wiley.com/doi/10.1002/bmb.50

17. United States Department of Education (USDOE). 2018 (Modified 3/1/2018). "Laws \& Guidance: Family Education Rights and Privacy Act (FERPA).” Accessed online 1/27/19 at: https://www2.ed.gov/policy/gen/guid/fpco/ferpa/index.html 
18. Buelow, J.R., Barry, T., Rich, L.E. "Supporting Learning Engagement with Online Students.” Online Learning. v22, n4, p313-340, Dec 2018. Available:

https://files.eric.ed.gov/fulltext/EJ1202338.pdf

19. Hegeman, J. "Using Instructor-Generated Video Lectures in Online Mathematics Courses Improves Student Learning”. Online Learning. Volume 19, Issue 3. Pp. $70-87$ (2015).

Available: https://files.eric.ed.gov/fulltext/EJ1067530.pdf

20. Getzlaf, B., Perry, B., Toffner, G., Lamarche, K., Edwards, M. "Effective Instructor Feedback: Perceptions of Online Graduate Students.” Journal of Educators Online. Vol. 6, No. 2. July 2009. Available: https://eric.ed.gov/?id=EJ904070

21. Wiggins, G. "Seven Keys to Effective Feedback." Educational Leadership. Vol 70., No. 1. pp. 10-16. 2012. Available: http://www.ascd.org/publications/educational-leadership/sept12/vol70/num01/Seven-Key $\underline{\text { s-to-Effective-Feedback.aspx }}$ 